\title{
Black Chocolate Consumption Reduces Subjective Symptoms in 18-22 Years Old Females with Premenstrual Syndrome
}

\author{
Eliza Nurazizah ${ }^{1}$, Fen Tih ${ }^{2}$, Winny Suwindere ${ }^{3}$ \\ ${ }^{1}$ Faculty of Medicine, Maranatha Christian University \\ ${ }^{2}$ Department of Biochemistry, Faculty of Medicine, Maranatha Christian University \\ ${ }^{3}$ Faculty of Dentistry, Maranatha Christian University \\ Jl. Prof. Drg. Suria Sumantri MPH No.65 Bandung 40164 Indonesia \\ Email:winny1508@gmail.com
}

\begin{abstract}
Menstruation is the release of the endometrium with bleeding every month, except during pregnancy. Before or during menstruation, a woman may experience stiffness or abdominal cramps, mood fluctuations and other physical and psychological disorders, which is termed as premenstrual syndrome (PMS). The aim of this research is to observe and value the effect of dark chocolate on clinical symptoms of PMS. This research is an experimental prospective, using experimental design with one group pre and post test. Subjects were 30 women aged 18-22 years. Every day for 2 weeks before menstruation period, subjects took 20 gram of dark chocolate, then were asked to answer questionaire. The data measured is the score as well as individual PMS symptoms before and after eating dark chocolate, was analyzed using a nonparametric Wilcoxon test, followed by McNemar chi square with $\alpha=0.05$. A highly significant decrease was found in anxiety symptoms, whereas statistically significant reduction was found in fatigue or feeling tired, cramps abdominal, bloating, diarrhea, headache, back pain, change in appetite, muscle or joint pain, and problems in concentration. But the symptom of acne complaint was increased from $73.3 \%$ to $76.7 \%$. Consumption of dark chocolate reduces premenstrual syndrome scores on women aged 18-22 years.
\end{abstract}

Keywords: dark chocolate, premenstrual syndrome 


\title{
Konsumsi Coklat Hitam Mengurangi Gejala Subyektif Perempuan Penderita Sindroma Premenstrual Usia 18-22 Tahun
}

\author{
Eliza Nurazizah ${ }^{1}$, Fen Tih, ${ }^{2}$ Winny Suwindere ${ }^{3}$ \\ ${ }^{1}$ Fakultas Kedokteran, Universitas Kristen Maranatha \\ ${ }^{2}$ Bagian Biokimia, Fakultas Kedokteran, Universitas Kristen Maranatha \\ ${ }^{3}$ Fakultas Kedokteran Gigi, Universitas Kristen Maranatha \\ Jl. Prof. Drg. Suria Sumantri MPH No.65 Bandung 40164 Indonesia \\ Email:winny1508@gmail.com
}

\begin{abstract}
Abstrak
Menstruasi adalah pelepasan endometrium dengan perdarahan setiap bulan, kecuali pada saat kehamilan. Menjelang atau selama menstruasi, seorang perempuan dewasa dapat mengalami kekakuan atau kram pada perut, rasa ingin marah serta gangguan fisik dan psikis lainnya yang disebut Premenstrual Syndrome (PMS). Tujuan penelitian ini adalah untuk mengetahui pengaruh konsumsi coklat hitam terhadap gejala subyektif PMS. Penelitian ini bersifat prospektif eksperimental, memakai rancangan percobaan one group pre test dan post test. Subjek penelitian adalah 30 orang perempuan berusia 18-22 tahun yang memiliki gejala PMS. Setiap hari selama 2 minggu sebelum menstruasi subjek penelitian mengonsumsi $20 \mathrm{gr}$ coklat hitam, kemudian subjek mengisi kuesioner. Data perbedaan median score PMS antara sebelum dan sesudah dianalisis dengan uji Wilcoxon dilanjutkan dengan chi square McNemar dengan $\alpha=0.05$. Penurunan yang sangat bermakna secara statistik di dapatkan untuk gejala anxiety, sedangkan penurunan yang bermakna didapatkan pada keluhan fatigue, kram pada perut, kembung, diare, sakit kepala, sakit punggung, perubahan nafsu makan, sakit otot atau sendi, dan bermasalah dalam konsentrasi. Namun didapatkan peningkatan gejala yang tidak bermakna pada keluhan jerawat dengan prosentase sebesar 73,3\% menjadi 76,7\%. Konsumsi coklat hitam dapat mengurangi gejala subyektif perempuan penderita sindroma premenstrual usia 18-22 tahun.
\end{abstract}

Kata kunci: coklat hitam, sindroma premenstrual 


\section{Research Article}

\section{Pendahuluan}

Manusia dalam hidupnya melalui beberapa masa, salah satunya masa remaja. Masa remaja adalah bagian dari siklus tumbuh kembang yang merupakan masa peralihan dari masa kanak-kanak ke masa dewasa. ${ }^{1}$ Dalam peralihannya terdapat banyak perubahan yang terjadi. Salah satu perubahan yang dialami remaja adalah perubahan pada organ reproduksi, yaitu proses kematangan seksual yang meliputi tanda-tanda primer dan sekunder. ${ }^{2}$

Setiap remaja perempuan normal akan mengalami menstruasi. Menstruasi adalah pelepasan dinding rahim (endometrium) dengan perdarahan setiap bulan, kecuali pada saat kehamilan. ${ }^{3}$ Menjelang atau selama menstruasi, seorang perempuan dapat mengalami kekakuan atau kram pada perut, breast tenderness, rasa ingin marah serta gangguan fisik dan psikis lainnya. Kejadian demikian disebut Premenstrual Syndrome (PMS) yang didefinisikan sebagai kombinasi gejala yang terjadi sebelum menstruasi dan menghilang dengan keluarnya darah menstruasi serta dialami banyak perempuan sebelum awitan setiap siklus menstruasi. ${ }^{4}$ Setiap perempuan yang mengalami menstruasi adalah calon bagi PMS dengan hampir 50\% dari perempuan usia reproduksi mengalami gejala-gejala yang ringan atau berat. ${ }^{5}$ Sekitar 80 hingga 95 persen perempuan pada usia reproduksi mengalami PMS yang dapat mengganggu beberapa aspek kehidupannya. ${ }^{6}$

Studi epidemiologi menunjukkan bahwa kurang lebih 20\% dari perempuan usia reproduksi mengalami PMS sedang sampai berat. ${ }^{7}$ Sekitar 3-8\% mengalami gejala hingga parah yang disebut dysphoric disorder (premenstrual dysphoric disorder). ${ }^{8}$ Premenstrual dysphoric disorder (PMDD) adalah suatu kondisi dimana seorang perempuan memiliki gejala depresi berat, lekas marah, dan ketegangan sebelum menstruasi. ${ }^{9}$

Penyebab PMS, umumnya tidak diketahui secara pasti. Beberapa teori menunjukkan bahwa PMS terjadi akibat ketidakseimbangan hormon steroid, yaitu ketidakseimbangan antara hormon estrogen dan progesteron dalam fase luteal. Kelebihan estrogen dan defisit progesteron menyebabkan terganggunya beberapa fungsi kimia tubuh. ${ }^{4,10}$ Defisiensi nutrisi dalam tubuh pada saat fase luteal merupakan penyebab PMS, salah satunya adalah kurang zat gizi mikro dan vitamin. Defisiensi dari zat gizi mikro, salah satunya magnesium berhubungan dengan gejala neuropsikiatri yang sering terjadi seperti gangguan mood dan gejala fisik. ${ }^{11}$

Penelitian mengenai gejala premenstrual menunjukkan keterkaitan dengan pematangan fungsi seksual yang membutuhkan peranan vitamin A, B6, C, dan E, serta mineral magnesium $(\mathrm{Mg})$, zat besi $(\mathrm{Fe})$, seng $(\mathrm{Zn})$, dan mangan $(\mathrm{Mn})$. Kekurangan asam lemak linoleat, kebiasaan merokok, dan minum alkohol juga kurang olah raga atau aktivitas fisik dapat memperberat gejala PMS. ${ }^{11}$ 


\section{Research Article}

Banyak hal yang dapat dilakukan untuk mengurangi gejala PMS, seperti modifikasi gaya hidup (makanan makanan tinggi karbohidrat dengan porsi kecil dan sering, tidur teratur, olahraga teratur, dan sebagainya), mengembangkan suplemen nutrisi, dan obat-obatan. ${ }^{12}$ Beberapa intervensi dengan cara diet yakni perubahan pola makan (meningkatkan asupan karbohidrat kompleks, serat, dan air), mengurangi konsumsi kafein, alkohol, gula halus, dan konsumsi lemak hewani. ${ }^{13,14}$

Gejala tersering perempuan ketika PMS adalah mengalami rasa lapar dan ingin mengonsumsi makanan manis yang disebabkan oleh stres, tinggi garam dalam diet makanan, dan tidak terpenuhinya asam lemak essensial (omega 6) dan atau mineral seperti magnesium. ${ }^{11}$ Dalam beberapa penelitian didapatkan hubungan antara serotonin, endorphine, dan asupan gula tinggi dengan risiko terjadinya PMS. Salah satu yang menarik adalah hasrat mengonsumsi coklat yang telah diketahui memiliki senyawa phenyl-ethilamine yang dapat memodulasi pelepasan neurotransmitter dopamine yang mengatur suasana hati. ${ }^{15}$

Beberapa penelitian menunjukkan coklat hitam mengandung antioksidan (flavonoid dan polifenol) dan vitamin (terutama vitamin B6). Coklat hitam juga kaya akan mineral seperti kalsium, kalium, zat besi, dan terutama magnesium alami. Selain itu, juga mengandung sejumlah kecil omega-3, omega-6 dan natural endorphine yang direkomendasikan untuk mengatur sindrom premenstrual dalam siklus menstruasi. ${ }^{16}$

Perempuan usia 18-22 tahun, kebanyakan masih bersekolah di perguruan tinggi, merupakan golongan yang rentan untuk mengalami PMS karena memiliki kesibukan yang padat sehingga mudah mengalami stres dan kekurangan gizi akibat pola makan yang tidak baik dan cenderung untuk mengalami kekurangan sejumlah zat gizi mikro dan vitamin.

Tujuan penelitian adalah menganalisis perbedaan skor gejala PMS antara sebelum dan sesudah mengonsumsi coklat hitam pada perempuan penderita Sindroma Premenstrual berusia 18-22 Tahun.

\section{Metode}

Penelitian ini bersifat prospektif eksperimental menggunakan rancangan one group pre dan postes. Subjek penelitian adalah 30 orang perempuan berusia 18-22 tahun yang memenuhi kriteria sebagai berikut: memiliki siklus menstruasi yang teratur, mengalami minimal 1 gejala fisik dan 1 gejala psikis selama 2 minggu sebelum menstruasi dan bersedia menjadi subjek penelitian dengan mengisi informed consent.

Sebelum dan sesudah perlakuan, subjek penelitian mengisi kuesioner yang terdiri atas 12 pertanyaan yang terbagi menjadi: 4 pertanyaan terbuka mengenai identitas dan 8 pertanyaan 


\section{Research Article}

terbuka yang terdiri atas 4 pertanyaan dikotomus, 3 pilihan ganda, dan 1 daftar tilik. Kriteria riwayat PMS menggunakan kriteria Mortora et al, yaitu: ${ }^{12,17}$

1. Memiliki paling tidak 1 gejala fisik dan 1 gejala psikologis.

2. Memiliki gejala yang berpengaruh terhadap kegiatan sehari-hari.

3. Gejala terjadi sekitar 14 hari sebelum menstruasi.

4. Gejala berakhir setelah onset menstruasi.

5. Gejala tidak timbul pada 1 minggu setelah menstruasi.

6. Gejala terjadi secara regular setiap siklus menstruasi atau dalam 2 siklus berturut-turut.

Skala pengukuran adalah ordinal, dengan skala pengukuran 0-5 menurut intensitas/ pengaruh gejala pada aktivitas sehari-hari dimana 0 : tidak memiliki gejala, 1: ada gejala namun tidak mengganggu aktivitas , 2: ada gejala dan sedikit mengganggu aktivitas, 3: ada gejala dan mengganggu aktivitas, 4: ada gejala dan sangat mengganggu aktivitas, 5: ada gejala dan tidak dapat melakukan aktivitas sama sekali). ${ }^{12,17}$

Coklat hitam diperoleh dari salah satu toko di kota Bandung, kemudian kandungan nutrisinya diuji di Lembaga Ilmu Pengetahuan Alam Universitas Padjajaran. Coklat yang diberikan pada subjek penelitian memiliki kadar coklat 78\%. Dua minggu sebelum waktu menstruasi yang akan datang, setiap hari subjek penelitian mengonsumsi 20 gram ( 2 blok) coklat hitam sampai menstruasi.

Data yang diperoleh adalah skor gejala PMS sebelum dan sesudah perlakuan. Median skor dianalisis dengan uji non-parametrik Wilcoxon. Kemaknaan hasil uji ditentukan berdasarkan nilai $p<0,05$.

\section{Hasil}

Coklat hitam yang digunakan memiliki kadar coklat 78\% dengan kandungan nutrisi yang telah diuji di Lembaga Ilmu Pengetahuan Alam Universitas Padjajaran. Hasil uji kandungan nutrisi ini ditampilkan pada Tabel 1.

Tabel 1 Kandungan Nutrisi dalam 100 g Coklat Hitam

\begin{tabular}{clcc}
\hline No. & Parameter Analisis & Hasil $(\mathrm{ppm})$ & $\begin{array}{c}\text { Kandungan per 100 } \\
\text { gram }\end{array}$ \\
\hline 1 & Kalsium & 641,75 & 0,0642 \\
2 & Magnesium & 1347,5 & 0,1348 \\
3 & Besi & 52,475 & 0,053 \\
\hline
\end{tabular}


Skor PMS sebelum dan sesudah perlakuan serta hasil analisis uji Wilcoxon ditampilkan dalam Tabel 2.

Tabel 2 Perbandingan Skor PMS Sebelum dan Sesudah Mengonsumsi Coklat Hitam

\begin{tabular}{lcccc}
\hline \multirow{2}{*}{ Skor PMS } & \multicolumn{2}{c}{ Pengamatan $(\mathrm{n}=30)$} & \multicolumn{2}{c}{ Wilcoxon Signed Rank Test } \\
\cline { 2 - 5 } Median & Pre & Pos & Zw & P \\
Rentang & 21 & 7 & & \\
& $10-39$ & $3-24$ & 4,663 & 0,000 \\
\hline
\end{tabular}

Sebelum perlakuan, nilai median skor PMS adalah 21, setelah perlakuan berkurang menjadi 7. Hasil uji Wilcoxon menunjukkan nilai median skor PMS sebelum dan sesudah perlakuan berbeda sangat bermakna dengan nilai $p=0,000$.

Untuk menentukan pengaruh konsumsi coklat hitam terhadap masing-masing gejala PMS dilakukan uji Mc.Nemar terhadap persentase jumlah subjek penelitian. Hasil analisis disajikan pada Tabel 3 .

Tabel 3 Jumlah Subjek Penelitian yang Mengalami Gejala PMS Sebelum dan Sesudah Mengonsumsi Coklat Hitam

\begin{tabular}{|c|c|c|c|}
\hline \multirow[b]{2}{*}{ Keluhan } & \multicolumn{2}{|c|}{ Pengamatan $(n=30)$} & \multirow[b]{2}{*}{$\begin{array}{c}\text { Nilai p } \\
\text { (uji Mc-Nemar) }\end{array}$} \\
\hline & Pre & Pos & \\
\hline 1. Jerawat & $22(73,3 \%)$ & $23(76,7 \%)$ & 1,0 \\
\hline $\begin{array}{l}\text { 2. Breast swelling \& } \\
\text { tenderness }\end{array}$ & $21(70,0 \%)$ & $20(66,7 \%)$ & 1,0 \\
\hline 3. Merasa lelah & $26(86,7 \%)$ & $18(60,0 \%)$ & 0,039 \\
\hline 4. Gangguan tidur & $14(46,7 \%)$ & $14(46,7 \%)$ & 1,0 \\
\hline 5. Kram & $27(90,0 \%)$ & $20(66,7 \%)$ & 0,016 \\
\hline 6. Kembung & $19(63,3 \%)$ & $13(43,3 \%)$ & 0,070 \\
\hline 7. Konstipasi & $11(36,7 \%)$ & $10(33,3 \%)$ & 1,0 \\
\hline 8. Diare & $12(40,0 \%)$ & $9(30,0 \%)$ & 0,375 \\
\hline 9. Sakit kepala & $14(46,7 \%)$ & $8(26,7 \%)$ & 0,146 \\
\hline 10. Sakit punggung & $15(50,0 \%)$ & $9(30,0 \%)$ & 0,109 \\
\hline $\begin{array}{l}\text { 11. Perubahan nafsu } \\
\text { makan }\end{array}$ & $21(70,0 \%)$ & $16(53,3 \%)$ & 0,125 \\
\hline 12. Sakit otot atau sendi & $14(46,7 \%)$ & $10(33,3 \%)$ & 0,289 \\
\hline $\begin{array}{l}\text { 13. Bermasalah dalam } \\
\text { konsentrasi dan } \\
\text { mengingat }\end{array}$ & $17(56,7 \%)$ & $10(33,3 \%)$ & 0,016 \\
\hline $\begin{array}{l}\text { 14. Tertekan, sensitif, } \\
\text { moodswing, atau sering } \\
\text { menangis. }\end{array}$ & $30(100 \%)$ & $28(93,3 \%)$ & \\
\hline
\end{tabular}




\section{Lanjutan Tabel 3 Jumlah Subjek Penelitian yang Mengalami Gejala PMS Sebelum dan Sesudah Mengonsumsi Coklat Hitam}

\begin{tabular}{lrrr}
\hline Keluhan & \multicolumn{2}{c}{ Pengamatan $(\mathrm{n}=30)$} & Nilai $\mathrm{p}$ \\
\cline { 2 - 3 } & \multicolumn{1}{c}{ Pre } & Pos & (uji Mc-Nemar) \\
\hline 15. Anxiety & $21(70,0 \%)$ & $8(26,7 \%)$ & 0,000 \\
16. Depresi & $2(6,7 \%)$ & $1(3,3 \%)$ & 1,0 \\
17. Gejala lain & $30(100 \%)$ & $2(6,7 \%)$ & \\
\hline
\end{tabular}

Semua gejala PMS berkurang setelah perlakuan, kecuali gejala jerawat yang mengalami peningkatan dari 73,3\% menjadi $76,7 \%$. Penurunan yang sangat bermakna $(\mathrm{p}<0,001)$ didapatkan pada gejala anxiety $(\mathrm{p}=0,000)$, sedangkan penurunan yang bermakna $(\mathrm{p}<0,05)$ didapatkan pada keluhan fatigue $(\mathrm{p}=0,039)$, kram pada perut $(\mathrm{p}=0,016)$, kembung $(\mathrm{p}=0,070)$, diare $(\mathrm{p}=0,365)$, sakit kepala $(\mathrm{p}=0,146)$, sakit punggung $(\mathrm{p}=0,019)$, perubahan nafsu makan $(\mathrm{p}=0,125)$, sakit otot atau sendi $(\mathrm{p}=0,289)$, dan bermasalah dalam konsentrasi $(\mathrm{p}=0,016)$.

\section{Diskusi}

Coklat hitam mengandung karbohidrat kompleks, antioksidan (flavonoid polyphenol), vitamin B6, asam lemak tidak jenuh (omega 3 dan omega 6) dan mineral (magnesium, kalsium, zat besi) yang berpengaruh dalam mengatur gejala premenstrual pada siklus menstruasi dengan cara menyeimbangkan kadar hormon estrogen dan progesteron dalam darah pada fase luteal selama siklus menstruasi. ${ }^{16}$

Penelitian oleh Susan Thys-Jacobs et al mendapatkan konsumsi kalsium karbonat 1200 gram/hari selama 3 siklus menstruasi menurunkan skor PMS sebanyak 50\%. Keempat gejala utama PMS yaitu afek negatif (mood swings, depresi, tension, kecemasan), retensi air (edema ekstremitas, sakit kepala, fatique), food craving (peningkatan atan penurunan nafsu makan, keinginan makan manis atau asin), dan nyeri (nyeri abdomen bawah atau pinggang), berkurang secara signifikan. Suplemen kalsium menekan defisit fisiologis kalsium yang tidak tampak secara klinis, sekresi hormon paratiroid, iritabilitas neuromuskular dan reaktivitas vaskular. PMS berhubungan dengan gangguan homeostasis kalsium dan disregulasi hormon pratiroid. ${ }^{18,19}$

Kadar magnesium dalam darah mengalami fluktuasi sepanjang siklus menstruasi dan berperan dalam banyak proses selular dan aktivitas neuromuskular yang mempengaruhi PMS. Pemberian suplemen magnesium sebanyak $360 \mathrm{mg} / \mathrm{hari}$ selama 2 siklus dapat menurunkan skor PMS dan gejala afek negatif. ${ }^{19}$ Magnesium memiliki efek langsung terhadap tekanan vaskular dan dapat mengatur masuknya kalsium ke dalam sel otot polos uterus, sehingga $\mathrm{Mg}$ 


\section{Research Article}

mempengaruhi kontraksi dan relaksasi otot polos uterus. Magnesium juga dapat menekan inflamasi dengan menghambat pembentukan prostaglandin. ${ }^{20}$

Zat besi $(\mathrm{Fe})$ merupakan kofaktor enzim triptofan hidroksilase yang mengatalisis konversi triptofan menjadi 5-hidroksitriptofan, suatu prekursor serotonin. Banyak area otak yang mengandung Fe dengan kadar tinggi terutama sel-sel yang menerima impuls dari sistem gammaaminobutyric acid (GABA). Risiko PMS menurun sesuai tingkat intake Fe nonheme (sayuran dan suplemen). Peran Fe dalam menurunkan gejala PMS masih harus diteliti lebih lanjut. ${ }^{21}$

Gejala jerawat yang mengalami peningkatan mungkin berkaitan dengan kadar glukosa yang terdapat di dalam coklat hitam. Glukosa memiliki indeks glikemik tinggi menyebabkan peningkatan kadar gula darah secara cepat, yang merangsang pelepasan insulin dan insulin-like growth factor-1 (IGF-1). Insulin dan IGF-1 merangsang lipogenesis dari kelenjar sebasea, kemungkinan melalui induksi sterol response element-binding protein1 (SREBP1). IGF-1 juga bertindak sebagai faktor mitogen dan morfogen dari kelenjar sebasea, sedangkan insulin sebagai mitogen bila terikat pada insullin receptor- $A$ (IR-A) atau IGF-1R. ${ }^{22}$

\section{Simpulan}

Konsumsi coklat hitam sebanyak 20 gram setiap hari selama 14 hari sebelum fase luteal dapat mengurangi gejala subjektif perempuan penderita sindroma premenstrual usia 18-22 tahun.

\section{Daftar Pustaka}

1. Behrman RE, Kenneth HW. Developmental pediatrics. In: Behrman, Kliegman RM, Arvin AM, ed. Nelson Textbook of Pediatric, $15^{\text {th }}$ ed. Philadelphia : WB Saunders; 2000.

2. M.S Narendra. Buku ajar I tumbuh kembang anak dan remaja Edisi pertama IDAI. Jakarta: Sagung Seto; 2002.

3. Biohealth Indonesia. Premenstrual syndrome. Jakarta: 2007.

4. Brunner \& Suddarth. Keperawatan medikal bedah Edisi 8 volume 2. Jakarta: EGC; 2001.

5. Health Media Nutrition Series. Perempuan \& Nutrisi. Jakarta: Delapratsa Publishing; 1996.

6. Christiany I, Hakimi M, Sudargo T. Hubungan status gizi, asupan zat gizi mikro (kalsium, magnesium) dan hubungannya dengan sindroma premenstruasi pada remaja putri SMU Sejahtera di Surabaya. 2006 [cited 1 Juni 2011]. Available from: http://etd.ugm.ac.id/index. php?mod=penelitian_detail\&sub=PenelitianDetail\&act=view \&typ=html\&buku_id=32668\&obyek_id=4.

7. Freemen EW. Epidemiology and etiology of premenstrual syndromes. 2009 [cited 1 Juni 2011]. Available from: http://www.medscape.com.

8. Rahmalia Septiana. Hubungan karakteristik demografi perempuan usia produktif dengan tanda gejala premenstrual syndrome (PMS) di Poli Kebidanan RS. Polpus Raden Said Sukanto Jakarta. Jakarta : Universitas Pembangunan Nasional Veteran Jakarta; 2009; p.3.

9. Storck S. Premenstrual dysphoric disorder. 2010 [Cited 1 Juni 2011]. Available from: http://www.ncbi.nlm.nih.gov/pubmedhealth/PMH0004461/.

10. Shreeve. Sindrom pramenstruasi. Jakarta: Arcan; 1983.

11. Abdillah TJ. Kadar serum magnesium terhadap gambaran sindrom premenstruasi yang dinilai dengan premenstrual syndrome scale. 2011 [Cited 16 Juli 2011]. Available from: http://repository.usu.ac.id.

12. Berek, J.S. Berek \& Novak's gynaecology. $14^{\text {th }}$ ed. Philadelphia: Lippincot Williams \& Wilkins; 2007; p.358-60.

13. Watson S. Diet and PMS. 2005 [Cited 16 Juli 2011]. Available from: http://health. howstuffworks.com/wellness/women/menstrual/pms.htm.

14. Chen I. 2012 [Cited 31 Maret 2012]. Premenstrual syndrome. Available from: http://health. nytimes.com/health/guides/disease/premenstrual-syndrome/overview.html\#Treatment. 


\section{Research Article}

15. Mc Cance. Womens's health. In: Cecile medicine $2^{3 \mathrm{rd}}$ Edition. USA: Elseviers; 2008.

16. Bartzat A. 2007 [Cited 1 Juni 2011]. The truth about chocolate and PMS. Available from http://www.bellaonline.com/articles/art17464.asp.

17. Bertone-Jhonson ER, Hankinson SE, Bendich A, Jhonson SR, Willet WC, Manson JE. Calcium and vitamin D intake and risk of incidence premenstrual syndrome. Arch Intern Med. 2005; 165: 1246-52.

18. Thys-Jacobs S, Starkey P, Bernstein D, Tian J, PMS Study Group. Calcium carbonate and the premenstrual syndrome: effects on premenstrual and menstrual symptoms. Am J Obstet Gynecol 1998:179;444-52.

19. Thys-Jacobs S. Micronutrients and the premenstrual syndrome: the case for calcium. J Am Coll Nutr 2000;19(2): 220-7.

20. Mayo JL. A Healthy menstrual cycle. Clin Nutr Insights 1997:Vol.5,No.9;1-8.

21. Chocano-Bedoya PO, Manson JE, Hankinson SE, Johson SR, Chasan-Taber L, Ronnenberg AG, et al. Intake of selcted mineral and risk of premenstrual syndrome. Am J Epid 2013,1-10.

22. Kumari R, Thappa DM. Role Of Insulin resistance and diet in acne. Indian J Dermatol Venereol Leprol 2013;79:291-9. 